\title{
ENTRE PAQUE.
}

E "CATAÇÕES": A RITUALIZA DA BUSCA POR PARCEIROS TAS ELETRÔNICAS SOBRALEN 


\section{ENTRE PAQUERAS E "CATAÇÕES": A RITUALIZAÇÃO DA BUSCA POR PARCEIROS EM FESTAS ELETRÔNICAS SOBRALENSES}

\section{FA B RÍCIO SOUSA S A M P A I O}

DOUTORANDO EM CIÊNCIAS SOCIAIS PELA UNIVERSIDADE FEDERAL DO RIO GRANDE DO NORTE-UFRN/NATAL. 


\title{
ENTRE PAQUERAS E "CATAÇÕES": A RITUALIZAÇÃO DA BUSCA POR PARCEIROS EM FESTAS ELETRÔNICAS SOBRA- LENSES.
}

\section{Resumo}

A paquera masculina pode ser analisada 'enquanto' performance cujos rituais objetivam instaurar uma situação em que os envolvidos no flerte e a audiência mais próxima fiquem cientes do processo. Este artigo objetiva identificar e compreender os rituais que constituem a performance-paquera tomando como campo de observação etnográfica as festas eletrônicas que ocorreram na cidade de Sobral/CE no período de 2013 a 2016. Nesta discussão, a paquera foi dividida em fase preparatória, desfocada e focada a partir das teorizações de Erving Goffman (2009, 2010, 2011). Essas fases, bem como os rituais que as atravessavam, eram interseccionados por eixos de diferenciação corporal.

Palavras-chave: paquera, ritual, performance.

\section{BETWEEN FLIRTING AND MAKING OUT: THE RITUALIZA- TION OF THE SEARCH FOR PARTNERS IN ELECTRONIC PAR- TIES IN SOBRAL}

\begin{abstract}
Male flirting can be analyzed as a performance whose rituals aim to establish a situation in which those involved in the flirtation and the closest audience are aware of the ongoing process. This article aims to identify and understand the rituals that constitute the flirting- performance taking as an ethnographic observation field the electronic parties that occurred in the city of Sobral/CE during the period from 2013 to 2016. In this discussion, the flirting was divided into preparatory, out of focused and focused phases based on the theories of Erving Goffman (2009, 2010, 2011). These phases, as well as the rituals crossing them, were intersected by axes of body differentiation.
\end{abstract}

Keywords: flirting, ritual, performance. 


\section{ENTRE COQUETEOS Y "LIGUES". LA RITUALIZACIÓN DE LA BÚSQUEDA DE PAREJA EN LAS FIESTAS ELECTRÓNICAS DE SOBRAL}

\section{Resumen}

La coquetería masculina puede ser analizada como un performance cuyos rituales buscan instaurar una situación en la que los implicados y la audiencia más cercana son conscientes del proceso. Este artículo pretende identificar y comprender los rituales que constituyen el performance de la coquetería, tomando como campo de observación etnográfica las fiestas electrónicas que ocurren en la ciudad de Sobral/CE, durante el periodo de 2013 a 2016. Para esta discusión, la coquetería fue dividida en fase preparatoria, sin foco y enfocada, a partir de los aportes teóricos de Erving Goffman (2009, 2010, 2011). Esas fases, así como los rituales que las atraviesan, se cruzan con ejes de diferenciación corporal.

Palabras clave: coqueteo, ritual, performance.

Endereço do autor para correspondência: Rua tenente coronel elzio lima verde n.688, bairro; Renato parente, cidade -Sobral/ce. Cep -62033150. 


\section{INTRODUÇÃO}

Sobral é uma cidade do interior cearense que possui um território de $2.122,897 \mathrm{Km}^{2}$, uma população estimada, em 2015, de 201.756 habitantes $^{2}$ e se localiza a $250,3 \mathrm{~km}$ de distância da capital cearense, Fortaleza. Além da baixa densidade demográfica, os jovens entrevistados ratificaram a marcação religiosa do catolicismo como elementos que dificultavam a emergência de bares, festas ou espaços públicos de sociabilidade homossexual. É neste cenário social que surgiram festas "guetificadas"3 em suítes de motéis afastados do perímetro urbano da cidade que representavam, na época de sua emergência, um contexto cultural propício ao "soltar a franga" de jovens e adolescentes residentes na cidade ou em municípios vizinhos - Massapê, Senador Sá, Uruoca, Santana do Acaraú, Forquilha, Coreaú, Moraújo, Groaíras, Reriutaba, Varjota, Cariré, Pacujá, Graça, Frecheirinha, Miraíma, Meruoca e Alcântaras:

E se pode perceber que o maior público gay, não são daqui de Sobral, são de cidades vizinhas, que vem né? Estuda e aproveita, solta a franga ${ }^{4}$, né? Até tem uns que dizem assim, uns colegas meus: 'ah não vejo a hora de chegar sexta-feira para eu poder [...], não vejo a hora de chegar domingo para eu poder ir para Sobral'. Aí quando chega sexta-feira: 'aí, vou ter que voltar lá para minha cidade (Luís, 2016).

A etnografia da paquera realizada nas festas eletrônicas sobralenses entre os anos de 2013 a 2016 partiu da consideração dos processos de paquera 'enquanto' performances-rituais nos termos de Schechner (2012). A performance - comportamento permeado pelo ritual e jogo - se divide em ritual e entretenimento nos termos desse autor: a primeira se vincula à eficácia ou objetivo definido e a segunda busca passar o tempo ou obter prazer. Não existiria nem uma performance-ritual ou de entretenimento pura. Todas as performances transitariam entre esses dois polos (Op. Cit.). Assim, a paquera foi considerada como entretenimento e performance-ritual cuja expressividade de cada polo somente poderia ser compreendida com relação ao contexto em que a performance-paquera era realizada.

A concepção de ritual utilizada para analisar as performances-paquera foi balizada pelas considerações de Mariza Peirano (2001). Os rituais não são separados de outros comportamentos. Eles destacam, acentuam ou repetem os comportamentos usuais. A ritualização da paquera funcionava como acentuação de determinadas atitudes, comportamentos ou ações para definir uma situação de flerte reconhecível entre os envolvidos ou para uma audiência qualquer.

As festas observadas ocorreram em suítes de motéis ou em grandes clubes da cidade de Sobral-CE, tais como o Palmeiras Country Clube e o Coqueiros clube. Ao todo, foram realizadas quinze incursões em cinco diferentes festas eletrônicas consideradas gays pelos colaboradores da pesquisa. Os eventos festivos foram denominados de Estilo, Instinto, Paraíso, Tropical e Fantástica, cujos nomes surgiram de adjetivações 
extraídas dos discursos dos dezesseis jovens entrevistados em profundidade: Emanuel, Sócrates, Fábio, Alysson, João, Dênis, Jorge, Luís, Neto, Tiago, Marcos, Olavo, Ricardo, Aurélio, Ivo e Hugo. Este artigo foi construído a partir das discussões engendradas da pesquisa de doutoramento, realizada no período de 2013 a 2016, que objetivou compreender os rituais performáticos dos corpos masculinos em situações de paquera e "catação", nas festas eletrônicas da cidade de Sobral/ CE. A primeira parte é constituída por uma análise do surgimento e desenvolvimento das festas na cidade atentando para três fases que foram assinaladas pelos termos segregação, estabelecimento e massificação. A identificação de uma estrutura comum física e interacional constitui o segundo momento do artigo, que tem como sequência de análise os trânsitos performáticos dos jovens durante a noite e as fases rituais da paquera. E, para finalizar, os critérios sociais que classificavam o status de paquerabilidade dos corpos masculinos são analisados.

\section{1 - FESTAS ELETRÔNICAS DE SO- BRAL: DO SURGIMENTO À MASSI- FICAÇÃO}

O contexto social de surgimento das festas eletrônicas gays de Sobral/CE se deve à ausência desse tipo de evento na cidade e à inexistência de espaços sociais reconhecidamente direcionados à paquera ou "pegação" entre homens tais como boates, casas de show, bares, praças, cinemas, shopping e saunas. A ocorrência das primeiras festas coin- cidiu com a desativação do único bar considerado gay da cidade - Bardakal $^{6}$ - em 2012. As festas se configuraram - neste período - como a única opção de entretenimento e paquera "offline" entre homens que gostavam de música eletrônica e não queriam, ou não poderiam, viajar frequentemente para a capital cearense: ritual frequente para os jovens que objetivavam curtir esse tipo de festa de acordo com os colaboradores. João reitera a importância que essas festas assumiram para o público gay: "a homossexualidade é grande. E assim, essas pessoas elas não têm um local em que elas possam, em que elas se sintam mais à vontade, que não nessas festas. Então, essas festas são uma espécie de refúgio para alguns deles" (Hugo, 2016).

É uma festa para as pessoas dançarem, se divertirem, porque Sobral é uma cidade que não tem boates e festas, quando tem, são aquelas festas de forró, de sertanejo, que nem todo mundo gosta. Sobral nunca teve tradição em ter festa eletrônica e coisas parecidas. Então eu acho ela - principalmente para um público jovem e também para o público gay - tem uma certa importância, porque é uma festa que você também pode se sentir livre, seja você hétero, bissexual, gay, lésbica, não sei. Você pode ser quem você é lá na festa. Então acho que para esse público, ela tem uma importância sim (João, 2016).

Essas festas gays se tornaram o único espaço de entretenimento, paquera e saídas do armário de homossexuais das cidades vizinhas - principalmente de estudantes -, pois a cidade con- 
centrava duas universidades estaduais, uma federal, um campus do instituto federal de ensino, além de duas faculdades particulares:

As festas foram ficando falada e as pessoas foram perdendo a vergonha, tendo mais atitude. O público gls, sobral aqui está tomando de conta e não são gays que são daqui de sobral, são gays das cidades vizinhas. Pelo fato de na cidade deles, eles se reprimem diante da família, da sociedade. Então a única total liberdade deles se soltar é onde eles estudam que é aqui [...] (Luís, 2016).

Os eventos festivos eletrônicos em Sobral surgiram da realização de aniversários, comemorações e festinhas em motéis. Alguns sobralenses escolheram as suítes de motel há alguns anos para realizar festas entre pessoas conhecidas por terem baixo custo de realização e pela possibilidade de ultrapassar limites de duração dos eventos. Geralmente, os motéis mais frequentados da cidade se localizavam em bairros não-residenciais ou nas estradas que ligavam a cidade aos municípios vizinhos.

É, não, a festa de motel geralmente começou [...] fazendo aniversários: 'ah eu vou fazer meu aniversário aí o buffet é muito caro, no caso eu não posso fazer, o que eu posso fazer no motel, então vamos alugar a suíte e vamos fazer a bagaceira'. Começou assim, aí começou a dar certo, e as pessoas que geralmente faziam, e inclusive a Estilo daqui começou com o aniversário do cara que é um dos organizadores [...] elas vão se adaptando de acordo com que vai passando o tempo e vão mudando de nome, mas na verdade sempre existiu, certo. Só muda os locais, as estratégias, os nomes, [...] (Olavo, 2015).

Nas primeiras festas, o público era convidado via rede social apenas para os amigos e amigos de amigos dos organizadores desses eventos:

$\mathrm{E}$, quando eu fui, as primeiras vezes, as pessoas eram selecionadas, pelo grupo, no Facebook, acho que já existia o Facebook ou era Orkut, não lembro direito, mas enfim, eles faziam uma lista de pessoas e aí só entravam as pessoas que estavam com o nome na lista, certo! Então a primeira vez que eu fui, foi assim (Hugo, 2016).

Essas festas iniciais foram consideradas elitizadas pelos colaboradores em detrimento das outras que ocorrem atualmente nos clubes sociais da cidade. Eles acionaram cinco critérios para elitizar uma festa eletrônica gay sobralense: a classe social, a escolaridade, as performances de gênero, a faixa etária dos participantes e o local de realização do evento. Uma festa elitizada tinha um ingresso mais caro. A maioria dos frequentadores era de classe média ou rica que não morava em bairros periféricos da cidade e que cursava ou possuía nível superior de escolaridade. Normalmente, era uma festa realizada em espaços fechados ou em clubes sociais da cidade.

A elitização também era atribuída para as festas em que frequentavam homens mais maduros e ajustáveis ao padrão "fitness"7 e à masculinidade heterossexual.

Eu falo elitizado, mas em relação [...] nível social mesmo, nível social, nem falo, até pelo preço do ingres- 
so que era um pouco mais caro, e também acontecia no Palmeiras, que na época também era um pouco mais raro isso acontecer. Então, as pessoas que iam para Instinto - eu frequentava as duas na época - mas a Instinto foi a primeira festa que eu fui [...] E principalmente os rapazes mais velhos, assim... os gays mais maduros, eu percebia, mais maduros, mais fortes, que até chamam de barbie, hoje, atualmente, os gays mais fortes, costumavam frequentar mais a Instinto. Eu via isso. $\mathrm{Na}$ Estilo não. $\mathrm{Na}$ Estilo dava mais eram os adolescentes como eu na época [...] Mas eu falo em relação a elitizado é mais pelo preço do ingresso, pelas pessoas talvez, formação mesmo, é, formação acadêmica, que eu via que tinha pessoas mais instruídas na Instinto (Ricardo, 2016).

Nas primeiras edições, a paquera e a "catação" nessas festas eram sigilosas e reservadas. A homossexualidade ou a "curtição" entre homens deveria ser mantida no segredo e, quando descoberta, havia um acordo tácito de silêncio entre os participantes: "bebeu, se divertiu e tudo. E ficou ali. Tipo: o que a gente viveu no motel pronto, ficou ali [...]. Porque tipo assim, aí vai ter testemunha, aí vai ter outras pessoas que eu não conheço que podem saber o que eu estou fazendo aqui e tal" (Jorge, 2016).

Ninguém se beijava, se ficasse era muito escondido para que ninguém tivesse sabendo do fato que aconteceu. Até porque das duas vezes que eu fui assim, que foi realmente festa reservada, eu fiquei assim no sigilo total, porque meu grupo de ami- gos - que me convidaram - eu não tive coragem de dizer para eles que tinha um cara dando em cima de mim, que eu ia ficar com esse cara, eu não tive coragem (Luís, 2016).

Os "ficas" e as "pegações" eram realizados numa ambiência de "armário para dois". A festa - ao invés de se configurar num "gueto" gay para os frequentadores, pois a maioria tinha esse evento como único espaço de paquera/ "pegação" e interação liberada - funcionava como uma ampliação do armário. $\mathrm{O}$ medo de ser descoberto e ter sua homossexualidade publicizada por algum frequentador requeria um cuidado ritual nas paqueras/ "pegações" que eram concretizadas em espaços reservados, como os banheiros ou estacionamento interno das suítes dos motéis.

Aí todos que, estavam lá, eram pessoas que são gays né. Só que se reprimia, às vezes não tinha coragem, tinha vergonha. E então, era todo mundo dançando, bebendo e era aquela coisa, tipo assim, eu paquerava, mas não tinha coragem e nem a pessoa vinha. Aí um momento desprevenido do grupo de amigos que eu ia, que eu fui, um momento de fragilidade deles, que eles estavam ali se distraindo, eu pegava e dava uma fugidinha de ir no banheiro. Nessa ida no banheiro - eu não ia no banheiro - eu ia lá fora no estacionamento. Aí a pessoa que eu estava paquerando estava lá e a gente ficava escondido. E o total sigilo danado porque as pessoas ainda não tinham a atitude de chegar, por ser um [...] era tudo novo ali as pessoas [...]. Eram pessoas que quando estavam lá, 'a í valha 
fulanin trabalha em tal canto e está aquil Fulanin estuda em tal canto e está aqui, valha como assim' e era um público que acabou se enquadrando, se encaixando nessa Estilo (Luís, 2015).

Nessas festas iniciais guetificadas, a negociação da visibilidade era ritualmente revelada, embora os colaboradores admitissem que a maioria dos frequentadores era gay. Essa ambivalência de gueto e de visibilidade seletiva do desejo homossexual numa situação de "armário para dois" entre os frequentadores era justificativa pelo fato de que a cidade possuía baixa densidade demográfica e havia o risco eminente de algum jovem "rasgar" 10 para outras pessoas os fatos ocorridos na festa: a paquera e "pegação" entre homens. A maioria dos "ficas" eram praticados no sigilo para dois. Com o passar das edições das festas no motel, uma rede de "estabelecidos" $" 11$ foi sendo construída numa atmosfera elitizada de festa cuja maioria dos participantes era de conhecidos entre si, de classe média ou alta, formados ou estudantes universitários, de preferência não "rasgados"12 e de masculinidade musculosa. Nessa ambiência, a paquera/ "pegação" deixou de ser tão sigilosa, principalmente, pelo acordo tácito de não comentar sobre os acontecimentos da festa para "outsiders" e não-frequentadores. Nessa fase, os rituais de paquera poderiam ser ilustrados da seguinte maneira:

Houve uma mudança muito grande, foram etapas até as pessoas se conscientizarem que ali era uma festa gls, da atitude [...] da paquera, na curtição da paquera, do fica, do sexo [...] E tudo teve essa cons- trução, de início era só uma festa reservada, o meio termo foi que realmente todo mundo tomou iniciativa, começou a se conscientizar que era uma festa gls, que as pessoas, homens podiam se beijar, mulheres começam a se beijar e ficar. Foi a fase da construção [...] (Marcos, 2016).

As festas eletrônicas sobralenses - de acordo com o relato dos entrevistados - poderiam ser divididas em três fases em relação aos processos de paquera. A primeira estava relacionada à construção do "gueto" gay na cidade em suítes de motel. Neste período, os/ as participantes selecionados/as não paqueravam diretamente ou flertavam sigilosamente. E os "ficas" e as "pegações" eram realizadas numa ambiência de "armário para dois". A segunda fase se referia à consolidação da festa como "gueto", a intensificação da frequência dos "estabelecidos" e a constituição de um "armário para todos". As paqueras se tornaram frequentes e os "ficas" visíveis e públicos. Apenas as "pegações" eram realizadas em espaços propícios como o "dark room"13 ou em espaços exteriores da festa. E, na terceira fase - contemporânea -, houve uma diminuição das "catações" e uma intensificação da frequência de casais gays e lésbicas, como, também, heterossexuais. A massificação suscitou o afastamento do público da primeira fase - a autoconsiderada elite gay - promoveu a diversificação de frequentadores e, de certa forma, minimizou o estigma que essas festas carregavam: "[...] uma festa que vale tudo. Você chega lá e você vai beijar todo mundo e vai transar na frente de todo mundo. Sendo que não 
é assim, que funciona. Eu já conheci um relacionamento meu que eu tive e foi sério, eu conheci lá” (Fábio, 2016). A grande frequência das "figurinhas carimbadas de festa"14 e essa "mesmice" apontada por Luís constituíram as principais razões de afastamento recente de alguns colaboradores dessas festas. No tocante à paquera/ "pegação”, uma festa precisa ter seu público renovado. Sem a frequência de determinada quantidade de "outsiders" ou "carne nova": "acaba sendo chato para nós organizadores que, sempre vemos as mesmas pessoas e para quem vai também porque as pessoas vão para se divertir, mas faz parte da diversão, encontrar alguém para se relacionar [...]" (Ricardo, 2016).

O reconhecimento social dessas festas como gays - visto que existiam raves ${ }^{15}$ e festas eletrônicas consideradas héteros na cidade - estava relacionado tanto com a presença majoritária dos gays quanto à homossexualidade publicizada dos organizadores das festas, pelo menos entre os frequentadores e entre os usuários que curtiam a página das festas no Facebook. A homossexualidade - ou o rótulo GLS dos participantes e organizadores - era identificada pelo estilo de música que os frequentadores dessas festas gostavam:

As pessoas me perguntam, muitas vezes 'ah $[. . .]^{16}$ essas festas é somente para gays', eu falei 'não, vai quem gosta de música eletrônica, de música pop, mas o foco é o gls mesmo, é o gls porque, geralmente quem curte música eletrônica, das divas ${ }^{17}$, são os gays e as lésbicas, né (Ricardo, 2016).
Desde o surgimento, essas festas dependeram da rede social para selecionar os seus participantes - na primeira fase - e depois realizar propagandas para atingir o maior número de frequentadores - na terceira fase. Se num primeiro momento, o Facebook representou uma mídia de guetificação, na fase contemporânea, ele é o principal recurso de massificação e sustentáculo dessas festas.

Através do Facebook, criavam-se uma rede de amigos iminentes participantes dessas festas - anterior e posteriormente à realização das edições - que, por um lado, aumentava a quantidade de "estabelecidos" e por outro, constituía um dos principais rituais de paquera praticados pelos indivíduos conectados. No interior dessa rede, rituais de paquera eram realizados, ou seja, esses grupos formados no "online" se constituíam em contextos culturais de busca e/ou seleção por futuros alvos de paqueração anterior à realização dos eventos festivos. O Facebook tornava-se o contexto cultural "online" em que as paqueras eram iniciadas ou os pretensos "crush"18 eram selecionados. As festas, geralmente, se tornavam o espaço social de prosseguimento da paquera "online" como também o momento de realização do "fica".

Os colaboradores ratificaram a interdependência entre as festas e os processos de paquera realizados nas mídias digitais - Facebook e whatsapp, por exemplo. Essa conectividade incessante e o uso dos aplicativos de paquera/ "pegação" não diminuíam a frequência de pessoas no "offline": nos bares ou nas festas. Os indivíduos transitavam 
entre os contextos "online" e "offline" sem a possibilidade de afirmar a preponderância de um dos contextos isoladamente.

\section{2 - OS ESPAÇOS FESTIVOS E SUAS INTERAÇÕES}

As festas eletrônicas gays de Sobral possuíam quase a mesma estrutura física e organizacional - telão com clipes, jogo de dança, pista central com DJs, bares, espaço com som - e eram frequentadas pela maioria de "figurinhas carimbadas de festas". Esses eventos se diferenciavam das "raves" ou de outras festas consideradas heterossexuais:

[...] agora as festas de tipo rave, o que tem de diferente? O som é totalmente diferente, os DJs são diferentes [...] porque é assim, eles tocam uma vertente da música eletrônica, que apesar de eu fazer festa de música eletrônica, eles tocam, outra vertente, que é um som com mais batidas por minutos, um som mais rápido, um som mais pesado. E normalmente sem vocal. E nas minhas festas, a música eletrônica que rola é uma música curta, de rádio, música com vocal, música mais comercial, música popular. Essa é a diferença. E o público também tem diferença. O público em festa, você percebe que é um público 'teen', é um público que é mais extravagante, que veste assim, coisas que a gente não vê todo mundo usando na rua, entendeu? E já nas festas de, sei lá, de música eletrônica, só música eletrônica, sem ser música pop, já é um povo mais comportado, mas é um povo que não conhece aquele estilo, só estão ali porque a festa está rolando e não tem, talvez não tenha, outra coisa no dia para fazer [risos] (Emanuel, 2016).

Geralmente, após a entrada - nos clubes e nas suítes de motel -, existia um considerável tapete vermelho que findava no primeiro espaço da festa um painel com a logomarca do evento - onde os frequentadores, no início da noite - tiravam fotos entre si ou com as atrações performáticas e com os DJs. Esse espaço era ocupado nas primeiras horas do evento e, às vezes, organizado por um fotógrafo contratado. Após as edições realizadas, algumas fotos - tanto desse espaço como também das atrações e dos momentos das festas - eram selecionadas pelos organizadores e postadas nas páginas do Facebook. Essas postagens funcionavam como meio de divulgação e identificação dos indivíduos que não tinham ido às festas, mas queriam coletar informações, especialmente porque - anexados a essas fotos - sempre existiam comentários, sugestões e avaliações feitas pelos frequentadores de determinada edição. Ricardo descreve um ritual pessoal frequente em relação a isso: "eu fui, eu visitei o evento da festa. E aí, como eu não fui, a gente procura saber como foi a festa. E aí então eu fui ver, as postagens de quem foi para saber como foi, como tinha sido a festa". Outro espaço visualizado na maioria das festas era a projeção de clipes através de data show. Inicialmente, alguns jovens ficavam assistindo sentados em sofás ou mesas com cadeiras, dependendo da festa. Regularmente, depois de uma hora da manhã, duplas ou grupos de jovens se revezavam em 
performances de dança orquestradas pelas coreografias que estavam sendo exibidas no telão. Em algumas festas, o telão exibia também as propagandas dos patrocinadores do evento. $\mathrm{Na}$ Estilo, Tropical e Paraíso - especificamente - havia um espaço constituído de telão e um vídeo game de dança, o xbox. As festas - seus espaços e atrações - poderiam ser pensadas enquanto performance que objetivavam o controle da excitação de seus participantes. O tédio, o estresse e a tristeza - emoções desagradáveis - deveriam ser afastados pela organização dos espaços, das atrações artísticas e pela sequência ritual de músicas tocadas pelos DJs.

É, eu também separo o horário de cada DJ de acordo com os momentos da festa. Tipo, no início da festa eu boto o DJ que geralmente gosta de tocar funk, tocar pop. Quando a festa está mais ou menos uma ou duas horas, coloco um DJ que gosta de tocar funk e depois o DJ que gosta de tocar um eletrônico. E já de manhã, eu coloco um DJ que gosta de tocar mais batida, porque as pessoas já estão mais bêbadas, já escutam coisas mais agitadas. Então eu penso em vários fatores da festa. Tipo organizar uma festa é bem complexo, é bem complicado (Ricardo, 2016).

Como performance social de excitação, as festas eletrônicas sobralenses não apenas buscavam excitação mimética e a emoção compensadora dos contextos restritivos da vida ordinária (ELIAS, 1992: 105), mas, também, objetivavam controlar e/ou maximizar a excitação agradável dos participantes durante a permanência nos espaços.
Esse controle era necessário tanto para evitar emoções negativas quanto para produzir satisfações positivas que impulsionassem os frequentadores a retornarem e também realizarem comentários agradáveis nas redes sociais, especialmente o Facebook. Nessas festas, a busca de excitação também era realizada pelo consumo de bebidas alcoólicas quanto de drogas ilícitas. Estes "dispositivos de excitação" atuavam quase sempre, de acordo com os colaboradores, como impulsionadores nas investidas de paquera:

$\mathrm{Na}$ festa acho que eles, por causa da bebida, têm uma coragem maior, às vezes não chega ou mandar alguém. É, e, chegar lá com você, como nessa mesma festa que eu fui. O cara pegou, chegou e me abraçou, por trás. E aí tentou me dar um beijo. Aí eu saí, claro, do abraço (Fábio, 2016).

De forma geral, a performance-festiva possuía determinados rituais que eram reiterados pelos participantes edição por edição. Os grupos de amigos se formavam no início da noite e jantavam em algum restaurante ou lanchonete. Depois, "esquentavam"19 em algum bar gay da cidade (Tiago, 2014). Por volta da meia noite, eles chegavam aos locais das festas. Nos momentos iniciais, a performance festiva majoritária dos grupos era caracterizada pelo consumo de "bebidas quentes", conversas, brincadeiras e pela curtição das músicas tocadas. Nessa fase, existia uma intensa circularidade dos "estabelecidos" entre os grupos formados, mas eles sempre retornavam aos seus grupos iniciais. Parece que a bebida alcoólica comprada, por vezes 
com a contribuição de todos integrantes do agrupamento, funcionava como elemento aglutinador dos grupos.

Por volta de uma ou duas horas da manhã, alguns integrantes se desprendiam de seus grupos para paquerar. Durante esse período denominado nessa discussão por "hora da pegação", alguns grupos se encontravam totalmente desfeitos e a maioria dos seus participantes se encaminhava para a pista de dança central da festa. Próximo das cinco da manhã, os grupos se refaziam com alguns integrantes que "não, [tinha ido] embora, casados" (Luís, 2015) da festa e organizavam suas retiradas do evento.

Existem pessoas que vão atrás mesmo, saem, deixa... vem com os amigos - lembra daquele lance de não ir só - deixa os amigos lá e se manda. O que eles chamam de 'catar', já ouviu essa expressão? Hoje em dia, vão catar, entre aspas. E sai e ficam com dois, três, quatro e por aí vai, entendeu? (Marcos, 2016).

$\mathrm{Na}$ "hora da pegação", a atividade principal se dirigia às paquerações, a busca por "ficas" ou "catações". A atenção com as atrações, as bebedeiras e as brincadeiras entre amigos e conhecidos tornavam-se envolvimentos laterais em relação às "catações" e aos flertes, agora envolvimentos principais e dominantes. Nesse período, o tipo de paquera mudava. Nos momentos iniciais da festa, a paquera era mais reservada, desfocada ${ }^{20}$ e caracterizada por gestos corporais cautelosos e seletivos. Depois das quatro, a fala se tornava menos presente, o corpo já cansado e alcoolizado perdia um pouco seu poder performativo e as investidas se tornavam mais "descaradas" (Marcos, 2016). O jogo de vaidades - transversal aos processos de paquera - era secundarizado em detrimento de uma preocupação maior: o "ficar", ou seja, não sair da festa sozinho ou sem "pegar ninguém” (Tiago, 2014).Vale ressaltar que inúmeros eventos marginais ocorriam para além dessa estruturação geral descrita. Alguns frequentadores apenas chegavam na "hora da pegação" ou adentravam sozinhas a festa. Outros participantes não se engajavam em nenhum grupo, embora circulassem por quase todos os grupos presentes. E outros indivíduos permaneciam a festa quase toda em determinado espaço, por exemplo, no bar ou nas proximidades do vídeo game de dança. As festas sobralenses eram "regiões abertas" no tocante aos investimentos focados de paquera. A pista central de dança - onde se localizavam os DJs - era o principal espaço aberto onde ocorriam as paquerações interseccionadas pelo grau de proximidade entre os participantes e pela quantidade de frequentadores "outsiders" ou novatos. O grau de abertura aos investimentos desses espaços estava condicionado aos períodos de desenvolvimento das festas e dos trânsitos entre os participantes. $\mathrm{O}$ "dance" principal poderia, muitas vezes, se tornar o pior lugar para paquerar, porque, além de ficar quase vazio, as pessoas ficavam dispersas nas laterais. Nessa situação, as investidas eram facilmente visualizadas e, por isso, desencorajadas pela possibilidade do "fora" - interação que poderia constranger os paqueradores que tomavam iniciativa. Além disso, o esvaziamento do "dan- 
ce" possibilitava visualizar os "pegadores": indivíduo avaliado negativamente por "dar em cima de muita gente" (Sócrates, 2014) ou colecionar "ficas". Alguns entrevistados enfatizaram que, geralmente, quando o "dance" estava vazio, contavam a quantidade de "ficas' destes "pegadores" e informavam aos seus amigos e conhecidos que estavam na festa com a intenção de avisá-los para não investirem nesse participante.

\section{3 - RITUAIS DE PAQUERA}

A título de análise, aos processos de paquera foi aplicada uma divisão balizada nas teorizações de Erving Goffman $(2009,2010,2011)$. A paquera foi dividida nas fases preparatória, "desfocada" e "focada". Durante a primeira fase, o indivíduo atuava na construção de um "porte bom", nas palavras de Goffman (2011): ou a criação e sustentação de uma imagem de si com qualidades desejáveis para os outros. Essa fase poderia ocorrer antes de entrar nas festas ou em momentos que antecediam a busca por parceiros durante a festa: o cálculo e o desejo atravessavam a construção da performance a ser executada em determinado contexto.

A fase desfocada era auxiliada pelo "ritual do esquadrinhamento" e pelas infrações a "desatenção civil". Nas "interações desfocadas", os indivíduos na "copresença" não compartilham de um único foco de atenção (Op. Cit.) ao contrário da "interação focada" onde existe um único foco de "atenção cognitiva e visual" durante os atos de fala e gestos dirigidos (GOFFMAN, 2011: 128).
A "desatenção civil" é um ritual de identificação da presença dos indivíduos entre si através do olhar nos olhos (GOFFMAN, 2010: 108). A infração a esse ritual poderia iniciar a paquera porque trabalhava os olhares de confirmação da presença um do outro e, dessa confirmação, a mutualidade de interesse amoroso ou sexual poderia surgir, de acordo com os entrevistados.

O "ritual do esquadrinhamento" era o primeiro e transversal ritual de paquera/ "catação" que objetivava não apenas selecionar os possíveis alvos amorosos e/ou sexuais de investimentos a partir de critérios como "afinidade", "beleza física" ou "pessoas de conteúdo” (Hugo/2016). Mas também, buscava minimizar a possibilidade do "toco" ou "fora" resultante das previsíveis decepções de "não bater a química”21 (Fábio/2016).

Nos momentos iniciais dos eventos, os indivíduos chegavam, buscavam por amigos e se integravam em pequenos grupos. Ao mesmo tempo em que interagiam nos seus grupos, eles observavam os outros participantes da festa. Os participantes sozinhos que não se engajavam em nenhum grupo - por opção ou por estarem frequentando determinada festa pelas primeiras vezes - ficavam transitando, 'tateando' o espaço e se posicionavam, geralmente, às margens da pista de dança central. No começo da festa, o esquadrinhamento pretendia: "observo todo mundo que está ali ao meu redor. Todo mundo que está ali ao meu redor, Conheço, conheço, conheço. Não conheço, bonitinho, não sei o que e aí a gente faz uma pré-analisada, em todo mun- 
do" (Neto, 2015).

$\mathrm{Eu}$ vou responder mais observando as pessoas e [...]olhando para mim mesmo, dando a minha opinião. $\mathrm{O}$ que eu observo muito nas festas é que no início da festa, está todo mundo ali muito calmo, a música é mais dançante do que, batida. Então está todo mundo muito tímido, no início da festa, está tudo muito assim tímido. E aí as pessoas precisam, começar a beber alguma coisa para se encorajarem. Para ter atitude de chegar, em quem elas, querem (Ricardo, 2016).

Talvez pelo fato de que o "corte" ou o "fora" seja produtor de constrangimento, as aproximações no início da festa eram cuidadosamente estudadas pelo paquerador a partir da análise de vários sinais expressivos do corpo - ritual do esquadrinhamento - e, muitas vezes, era compreensível que ambos esperassem que o outro se aproximasse. Esperar ser paquerado ou, pela iniciativa de alguém para a interação verbal da paquera, foi considerado, pelos entrevistados, tanto uma proteção contra os constrangimentos quanto posturas de positivação ou valorização de si durante o mercado noturno da paquera.

Durante a fase desfocada da paquera - também denominada pelos colaboradores de "atirar para todos os lados" - que poderia ser realizada a qualquer momento e espaço da festa, por exemplo, na entrada ou nos trânsitos pelo "dance" principal - os jovens ofereciam a "desatenção civil". Através dessa cortesia, o ritual de esquadrinhamento dos participantes era executado e os futuros alvos de olhadelas mútuas eram identificados.

As olhadelas mútuas instauravam a fase focada da paquera. O olhar de paquera era diferenciado pelos colaboradores pela fixação, repetição, piscadelas e sorrisos. Diferentemente de um olhar comum, na paquera:

Acho que paquera é isso, de demonstrar de alguma forma, pelo olhar. É pelo olhar que é diferente quando a gente olha quando está interessado em alguém [...] pelas expressões faciais, pela boca, ou até algum gesto com a mão chamando a pessoa [...]. Você olha meio que de rabo de olho, às vezes, ou pisca o olho. Tem gente que chama com a mão [...]. Quem tem mais coragem chama (Alysson, 2016).

Se estar em grupos era a regra de conduta dos participantes das festas, qualquer saída provisória do engajamento nesses grupos era interpretada como paquera ou "catação". Neste ínterim, outra regularidade nas sociabilidades dessas festas foi sendo construída o uso do "cupido": uma espécie de intermediário/a que possuía a função de se aproximar do alvo de paquera de alguém. Ele/ela utilizava a "deferência"22 nas aproximações e, na maioria das ocasiões, perguntava pelo nome e o status amoroso de determinado participante. O uso do cupido poderia ser realizado estando em grupos. Os cupidos geralmente eram acionados para evitar a "catação" - ritual que, muitas vezes, era ridicularizado entre alguns participantes de determinado grupo. A "performance-cupido" representou uma alternativa sociogrupal construída de conciliação entre a regra de permanecer em grupos de amigos durante as 
festas, as intencionalidades de paquera dos coparticipantes e o medo ou vergonha de tomar iniciativa por causa da possibilidade do "fora". Mas a ação do cupido não era tributária de confiabilidade por todos os participantes:

É mais ou menos assim. O cupido ele pode ajudar, mas ele pode atrapalhar. Ele pode querer te empurrar a uma pessoa horrível, feia, a uma pessoa errada, um marginal, um usuário de droga, qualquer coisa do tipo, porque seja amigo dele e aí tu tens que ficar porque tu és amigo dele. Em outros casos não, ele te ajuda com pessoas que tu não tens contato e tu achou bonitinho, tu queres, mas tu não tens coragem de falar. Aí vai lá o cupido amigo e joga na maior para o cara. Aí às vezes o cara quer e às vezes o cara não quer [...], ainda mais ele não sendo daqui, aí às vezes o outro nem aí, deu certo deu se não deu, bola para frente (Neto, 2015).

De forma geral, o encontro conversacional - ou interação focada de paquera nas festas - iniciava com os rituais da "deferência", geralmente os de apresentação através de saudações e elogios. As perguntas iniciais, saudações e comentários - sobre as atrações ou sobre a festa como um todo - constituíam ações daquilo que os colaboradores denominavam "quebra-gelo”. Esse ritual era constituído pelas seguintes perguntas: "oi, tudo bem, é, está sozinho, está acompanhado...” (Sócrates, 2016); "ah chega pergunta: 'opa, e aí como é que está, beleza, está gostando da festa, como é teu nome? ' Às vezes nem pergunta o nome hoje em dia, eu ainda pergunto o nome.
Aí: 'está gostando, está sozinho, está acompanhado" (Olavo, 2015).

Talvez comece falando, sobre a festas, falando que está calor, alguma coisa, mas eu vou falar de mim. Eu, dependendo da pessoa que for, eu vou começar com um assunto em comum, perguntar... talvez, uma música, perguntar onde ela mora, se é a primeira vez que ela foi na festa... e aí vai fluindo... eu acho que a conversa, essa conversa inicial, pode durar pouco tempo ou não. Dependendo de ambas as partes. No meu caso, não dura muito tempo não essa conversa (Ricardo, 2016).

Outra forma de deferência por rituais de apresentação eram os elogios que, frequentemente, eram acionados pela sua comprovável eficácia. Conforme os relatos, quando os elogios vinham de surpresa e por pessoas inesperadas, poderiam causar incômodo e até repulsa, principalmente advindos de corpos que não interessavam. Regularmente, os elogios praticados durante as iniciativas de aproximação de algum paquerador emitiam a mensagem de que o receptor deveria agir, isto é, responder com outro elogio ou fomentar a conversa através de perguntas "quebrar gelo”. Os entrevistados, por sentirem muita vergonha de "se chegar em alguém”, esperavam que, depois desses rituais de apresentação, o outro já tomasse a iniciativa de beijar ou emitisse algum gesto que demonstrasse satisfação ou interesse por eles terem tido a coragem de "se chegar". Depois dos rituais de apresentação - que instauravam o "engajamento de face" ${ }^{23}$ da paquera - a interação falada poderia 
seguir várias direções: culminar na pegação, ou seja, no "fica" rápido, denominada, aqui, como a última etapa da paquera; um dos envolvidos poderia iniciar rituais de evitação com a intenção de terminar o estado focado de paquera; ou a conversa poderia fluir por algum tempo. Durante o encontro conversacional ocorria também o esquadrinhamento da performance linguística, especificamente nas paqueras sem intenção de "pegação" / "catação" a priori. Nessa avaliação da conversa, os discursos proferidos funcionavam como indícios ou pistas da subjetividade do outro. Além disso, analisava-se pela linguagem as (im) possibilidades de ocorrer namoros, amizades, "ficas" e/ou "pegações". As performances linguísticas que impulsionavam os paqueradores continuarem no papo - após o esquadrinhamento das estilizações corporais via eixos de diferenciação que serão analisados na próxima seção - eram os retornos às perguntas, a simpatia, o grau de envolvimento nos assuntos propostos e a identificação da mesma intenção de paquera.

É, mas se a pessoa chegar com 'oi, prazer, meu nome é fulano e se apresenta e conversa um pouco, pelo menos conversar, uns dois minutos... não que seja padrão - tem que ser dois minutos - mas conversar um pouco antes. Isso, mostra que a pessoa não está interessada só no ficar de beijo, não só transar. O requisito de eu aceitar é isso (Fábio, 2016).

As principais razões identificadas pelos colaboradores para emitir desinteresse pela conversa e, consequentemente, pelo paquerado, eram a falta de corres- pondência das intencionalidades da paquera e a não identificação de afinidades com relação aos assuntos tratados rapidamente: "Se fosse uma pessoa que me agradasse, se fosse uma pessoa bonita, e se tivesse um papo legal [...] se tiver conteúdo [risos] é, se estuda [...] se trabalha com algum propósito legal, alguma..." (Sócrates, 2016).

Bem, o que me faz desistir logo no começo da conversa é que no começo você invadir a minha privacidade, se você fizer muitas perguntas, perguntas muito íntimas [...] se quiser rolar comigo, você quer se tornar meu amigo, assim, é, de conversar e tudo ... aí já vem logo com perguntas da minha intimidade, eu não gosto, eu corto logo. Acho que primeiro você se torna amigo, depois, quem sabe, você pergunta, pergunta mais íntima (Alysson, 2016).

A exigência do maior envolvimento de ambos sujeitos durante o papo perpassava a interação focada numa tentativa de identificar a possibilidade futura daquele encontro - o "fica", uma "pegaçao" ou o "fora" - expressos a partir de alguma "jogada" linguística ou sinal corporal de algum dos corpos envolvidos. $\mathrm{Na}$ paquera focada, os rituais de apresentação poderiam ser salteados e os paqueradores, depois da troca de olhares, poderiam solicitar sem rodeios para "ficar". Esse tipo de paquera - sem a deferência - ocorria, geralmente, depois das duas ou três horas da manhã em diante - na "hora da pegação":

É, tipo, você está ali, eu quero ficar com você, é claro que eu vou olhar para você. E aí você não vai 
olhar também né, querendo comer a pessoa. Mas você, é mais troca de olhares. E aí, da troca de olhares, aí vai chega, que normalmente chega a ficar mesmo né. A pessoa chega e, chega em você e fala, 'vamos ficar'. É mais ou menos assim (Fábio, 2016).

Geralmente, a infração aos rituais de "deferência", ocorriam durante a "catação" - o tipo de paquera que objetivava "pegação". Ela se assemelhava ao termo êmico "caçada", pois se configurava numa busca ritual por parceiros sexuais. Esse tipo de paquera era direta, rápida e o toque corporal era o ritual que se seguia ao olhar recíproco. Nessa situação social, qualquer "desatenção civil" poderia ser interpretada como "abertura" não somente aos processos de paquera, mas, acima de tudo, ao "fica" ou "pegação". Olavo denominou essa paquera como "chegar chegando":

Nem estava a fim de ficar com ninguém, mas a pessoa já chegou: 'olha eu gostei de ti' e já foi dando um beijo. Entendeu assim, pronto, 'chegou chegando', me desarmou por completo. Eu não tenho assim essa atitude toda não, mas eu achei muito massa e pronto fiquei a noite todinha com essa pessoa. Depois mantive contato pelas redes sociais [...] (Olavo, 2015).

As "catações" ocorriam geralmente depois de uma hora de funcionamento das festas: havia uma intensificação a partir das três horas da manhã. O "chegar chegando" poderia ser interpretado como subversão dos rituais de paquera reconhecidos pelos frequentadores das festas. Essa atitude não se desligava do primeiro ritual de instauração da situação de paquera, pois:

Primeiramente tem que ter a química do olhar, porque o olhar da pessoa tem que ver se rolou uma atração e tudo mais. Primeiramente, logo pelo olhar, e aí tem que ter a coragem de uma das duas, ou ambas, ter o pontapé inicial de chegar para conversar. Eu, no meu caso, muitas das vezes, quando eu estou a fim de uma pessoa, na festa, eu tomo iniciativa, mas eu acho muito massa quando a pessoa que eu estou a fim, toma a iniciativa (Ricardo, 2016).

Um dos principais marcadores da fase focada da paquera nas festas era a bebida. Ela foi identificada como um dispositivo que: produzia excitação, alegria e soltura nos eventos; impulsionava ou encorajava as investidas de paquera; e liberava/subvertia os corpos de outros dispositivos tais como o da sexualidade e do gênero performados durante a noite.

Tem pessoas que acabam tendo isso como um refúgio, não é o meu caso né, eu já vi assim pessoas que, utilizam a bebida como um certo refúgio para poder exibir algo que ela não exibiria em sã consciência, entendeu? Talvez é, estando mais alcoolizado, digamos assim, teria coragem de chegar na pessoa de dizer que está interessada na pessoa, que quer ficar com a pessoa, entendeu? É um dos fatores não é o meu caso né, hoje né. Mas eu já vi pessoas assim. Ficam mais..., perdem os pudores quando ficam bêbadas, entendeu? (Marcos, 2016).

O "toco" ou "corte" de paquera foi identificado como o ritual frequente- 
mente utilizado contra participantes cujo encontro conversacional "não bateu a química" ou "não rolou" (Ricardo, 2016). Esse ritual tanto poderia ser praticado de forma direta ou indireta. Os rituais de evitação indiretos acionados para o outro "se mancar", conforme os entrevistados, eram: não olhar para o outro; não perguntar muito, "responder com poucas palavras" (Hugo, 2016); manter o corpo distante do outro; fazer brincadeiras tolas e não corresponder aos toques que o outro aplicava durante as perguntas dirigidas.

A pessoa fica falando e eu digo, 'hum, ok!' Essas coisas, eu não respondo também a pergunta, eu faço só, responder assim só com um ok, que aí eu acho que já demonstra para pessoa que eu não estou a fim. E aí como já aconteceu, pessoas muito chatas, que continuam com umas perguntas horríveis, aí eu falei mesmo: 'eu não quero falar sobre isso', fui bem direto, 'eu não quero mais, mais falar', pronto (Alysson, 2016).

Esses rituais de evitação frequentemente executados de forma isolada - ou em conjunto - eram deduzidos pelos frequentadores como permissão para terminar o estado de fala ou a interação focada. Mesmo diante desses rituais, se o outro não se "tocava", a alternativa era a verbalização ou o "toco" direto: "vou procurar meus amigos", "vou ao banheiro", "vou pegar cerveja", "vou dar um rolé, volto já". Alguns insistiam: "bora, vou com você” (Dênis, 2014).

Cara eu procuro ser o mais sincero possível, senão as palavras, as minhas, ações. É, quando estou con- versando com alguém que não me interessa, o assunto, a pessoa, aí eu fico meio viajando, olhando para outro canto, meio que dizendo, 'ah! ', indiretamente, só com olhares, 'eu não estou a fim de papo, certo!'. Então eu fico tirando a minha própria concentração, enfim, olhando para os lados, eu acho que é isso (Hugo, 2016).

A sequência ritual da paquera entre homens nas festas eletrônicas descrita acima - fase preparatória, desfocada, focada, "fica" ou "toco - era atravessada pelo cálculo e pelo desejo amoroso e/ou sexual expresso de maneira performática e avaliados pelo ritual transversal do esquadrinhamento. O desejo e o cálculo constituíam operações subjetivas de classificar os corpos em paqueráveis ou não. Entretanto, essa classificação não ocorria de maneira voluntarista ou arbitrária. Existiam eixos de diferenciação social que os sujeitos acionavam para distinguir os corpos de maneira performativa nos termos de Butler (2002).

\section{4 - EIXOS DE DIFERENCIAÇÃO COR- PORAL}

Durante as fases dos processos rituais da paquera, o ritual de esquadrinhamento objetivava classificar/diferenciar os corpos masculinos numa espécie de atribuição de níveis de desejabilidade e/ou paquerabilidade para alavancar investidas ou "cortar" paquerações iniciadas. Os corpos eram singularizados e classificavam os seus alvos de paquera a partir de eixos sociais de diferenciação com a finalidade 
de valorizar ou estigmatizar determinadas performances ou configurações corporais. Nas paquerações, certos marcadores sociais da diferença eram acionados para designar corpos como fonte de emergência do desejo amoroso e/ou sexual. Sexo, "performance de gênero" ${ }^{24}$, sexualidade, padrão "fitness", classe, geração e "performance grupal" 25 constituíram os eixos que diferenciavam os corpos no mercado noturno das paqueras nas festas eletrônicas sobralenses.

Os corpos que paqueravam eram avaliados como: homens afeminados e/ ou "rasgados" ou másculos; homossexuais ou "que curtiam outros homens" ${ }^{\prime 26}$, malhados ou não-malhados, adolescentes, jovens, "coroas" ou "mariconas"; "gays de bairro" ou "gay fino" ${ }^{27}$; e que participavam de grupos de sociabilidade bem-sucedidos ou não. Essa classificação binária geral dos corpos para definir seus níveis de paquerabilidade estavam subordinadas e entrelaçadas de certa maneira a dois polos performáticos de gênero que foram detectados durante o desenrolar das entrevistas: a "performance máscula" e a "performance rasgada". Vale ressaltar que os colaboradores tanto se identificaram como afeminados ou másculos, mas em nenhum momento como "rasgados". O primeiro polo era mais valorizado e poderia positivar marcadores sociais considerados negativos como a classe social menos favorecida e a faixa etária: por exemplo, um homem másculo acima de trinta anos era denominado de "coroa" e se fosse malhado, "coroa enxuto". O segundo polo representava os corpos estigma- tizados: os afeminados que se "rasgavam" ou seja, dançavam de maneira feminina durante a festa. Esse estilo feminino de dançar era avaliado pela correspondência das coreografias com as danças praticadas pelas "divas do pop" e seus/suas bailarino/as. A esse polo, outros marcadores negativos poderiam se entrelaçar para inviabilizar determinado corpo como desejável e paquerável: se pertencesse a periferia, era denominado "gay de bairro" ou "viado pão com ovo"; se não fosse malhado e acima dos trinta anos, era chamado de "maricona". Em suma, as "performances de gênero" sublinhadas nessa discussão como polos opostos performáticos - másculo e "rasgado" - representavam os tentáculos da heterossexualidade obrigatória nos processos de paquera masculina e se entrecruzava com outros marcadores para definir o nível de paquerabilidade e desejabilidade dos corpos.

Os colaboradores também eram guiados - nas interações de paquera e "catação" durante as festas - por um tipo de correlação entre estilo musical, sexualidade, performance de gênero, padrão "fitness", "performance grupal" e faixa etária. Em seus trânsitos durante a noite, os corpos eram avaliados através de dois polos de identificação e atribuição possíveis, embora eles reconhecessem as possibilidades de subversão dessas sequências de identificação na totalidade dos participantes das festas. O primeiro polo de categorização era formado pela sequência: adolescentes - estilo musical pop - dança coreografada - afeminado - passivo. E o segundo, iniciava com os "gays ma- 
duros" ou mais velhos - estilo house ou tribal - dança reservada e solta másculo - ativo.

Eu acho que o jeito de dançar influencia muito. Quando a gente vai dizer que uma pessoa é afeminada. É, principalmente quando toca o funk, na festa eletrônica, a gente pode ver quem são os rapazes mais afeminados e os que não são [...]. Bem, assim, os gays mais velhos que vão para a festa, eles são mais reservados. Entretanto tem também os que são afeminados, que dão pinta, que dançam, que não estão nem aí para a opinião dos outros. Mas, os gays mais maduros são mais contidos, eu acho isso [...], mas é porque na nossa sociedade, no nosso grupo 'gls', a gente acaba, rotulando né, os mais afeminados, as pessoas que curtem mais pop, que gosta mais de... dançar, se expor, já fala, 'ah viu aquele cara que dança, sobe no pole dance, dança igual a diva e tudo mais.'. Aí fala, 'ah, é passivo...'. $\mathrm{E}$ aí as pessoas acabam é, dizendo, rotulando se esse homem é passivo. Pelo fato da festa tocar mais pop, de ir pessoas que gostam mais disso e....acontece! (Ricardo, 2016).

Esses binarismos de atribuição categórica entre os participantes ligavam heteronormatividade ${ }^{28}$ a gostos musicais numa pretensão de constituir dois roteiros performáticos-padrão por onde os homens circulavam ou reiteravam no decorrer dos eventos. Nessa atribuição, o binarismo de gênero determinava o binarismo etário como dois polos opostos, cuja valorização recaia sobre o polo másculo. Os adolescentes afeminados eram identificados por sua preferência pelo estilo musical pop, ha- bilidade e conhecimento performático sobre as coreografias das "divas" e, por consequência, seriam passivos. Os "gays maduros" másculos se identificariam com os estilos de batidas mais fortes, como o tribal e o house ${ }^{29}$ e por via de regra, seriam ativos.

Então quem se identifica com esse nome [pop] são mais os adolescentes que querem dançar... e tudo mais [...]Tipo, os adolescentes, os mais jovens, tipo de dezoito e vinte anos, eles curtem mais um pop mesmo, aquele pop que toca nas rádios, mais as divas. Já o público mais velho, assim, os rapazes de vinte e cinco para cima, eles já gostam de um house que é uma batida mais forte, dos DJs de fortaleza. Isso, eu venho percebendo, durante as festas, mas o povo também curte muito o funk [...]. Na música eletrônica, quando toca, geralmente o pop, quando toca Lady Gaga ou Beyoncé, essas duas, Lady Gaga e Beyoncé, o público que é mais afeminado sabe as coreografias. E aí dançam, se soltam mais, também no funk quando toca Anita, eles sabem fazer bem as coreografias que, de certa forma, eles saem do armário, ficam mais afeminadas [...]. Geralmente os que não são afeminados - os que aparentam não ser - eles não dançam muito na festa. Eles geralmente mexem um pé ou outro, um pouco a mão [...], mas eles não se soltam muito, eles ficam mais observando em pé os outros dançarem na festa [...] (Ricardo, 2016).

Nem todos os colaboradores partilhavam dessas sequências: "há gays para todo os tipos de gosto, que gosta de balada, que gosta disso, que gosta da- 
quilo. Têm gays que gostam de pagode, tem gays que gostam forró, tem gays que gostam de internacional, tem gays que gostam de brega, entendeu?" (Neto, 2015).

A performance de dança também marcava a paquera nas festas eletrônicas e agenciava o desejo ou poderia levar ao "corte" dos processos de paquera em curso:

Eu acho que o jeito de dançar influencia muito. Quando a gente vai dizer que uma pessoa é afeminada. É, principalmente quanto toca o funk, na festa eletrônica, a gente pode ver, quem são os rapazes mais afeminados e os que não são [...]. Bem, assim, os gays mais velhos que vão para a festa, é, eles são mais reservados. Entretanto tem também os que são afeminados, que dão pinta, que dançam, que não está nem aí para a opinião dos outros. Mas, os gays mais maduros são mais contidos, eu acho, isso [...] mas é porque na nossa, sociedade, no nosso grupo, no nosso grupo de, gls, a gente acaba, rotulando né, os mais afeminados, as pessoas que curtem mais, pop, que gosta mais de... dançar, se expor, já fala, 'ah viu aquele cara que dança, sobe no pole dance, dança igual a diva e tudo mais.'. Aí fala, 'ah, é passivo...'. E aí as pessoas acabam, é, dizendo, rotulando se esse homem é passivo. Pelo fato da festa tocar mais pop, de ir pessoas que gostam mais disso e....acontece (Ricardo/2016).

Em suma, os processos de paquera encerravam políticas de diferenciação dos corpos masculinos numa classificação oposicional e hierárquica para definir os seus níveis de desejabilida- de. A marcação da diferença corporal objetivava eleger determinados corpos como alvos de paquera. Assim, o desejo que justificava o investimento em algum ritual de paquera, era racionalizado através desses eixos. De forma geral, os corpos considerados desejáveis eram performativamente construídos com auxílio desses eixos oposicionais que funcionavam como moldes estilísticos por onde os corpos eram diferenciados.

\section{CONSIDERAÇÕES FINAIS}

As performance-rituais de paquera analisados das festas eletrônicas sobralenses corroboraram a reprodução da heteronormatividade nas sociabilidades homossexuais. Este artigo demonstrou processos gerais e hierárquicos de paquera cujo eixo norteador era a classificação dos corpos em "performance máscula" ou "rasgada" que se entrecruzava com os marcadores sociais da sexualidade, sexo, padrão "fitness", geração e "performance geral". Vale ressaltar que durante a etnografia foram observados outros processos de paquera não-hegemônica, ou seja, para além do binário "másculo-rasgado". Os afeminados paqueravam entre si, por exemplo. Esses processos de paquera podem constituir objetos de análise de pesquisas futuras correlacionadas.

\section{NOTAS}

${ }^{1}$ Esse termo êmico se refere à "pegação" ou "cruising". 
${ }^{2}$ Dados extraídos do site: http://cidades. ibge.gov.br/xtras/perfil.php?lang=\&codm un $=231290 \&$ search $=\mid$ | infogr $\%$ E1 ficos:-informa $\%$ E7\%F5es-completas. Acesso em: 14 ago. 2016.

${ }^{3}$ As primeiras festas eletrônicas sobralenses ocorriam numa atmosfera de "armário para todos" onde as práticas realizadas nesses contextos não deveriam ser publicadas de acordo com os colaboradores.

${ }^{4}$ Expressão êmica que significa liberação performática de estilos principalmente afeminados e/ou "rasgados", estigmatizados nos contextos familiares e citadinos específicos de cada participante que frequenta o evento e habita cidades com menor densidade demográfica do que Sobral/CE.

${ }^{5}$ Relaciona-se a buscas por sexo casual em locais públicos ou já consensualmente percebidos para esta finalidade: saunas, cinemas de sexo explícito, banheiros públicos e outros.

${ }^{6}$ De acordo com o relato, os jovens que frequentavam as festas eletrônicas julgavam as pessoas que participavam desse bar muito "afeminadas" e "rasgadas". Eles temiam que - ao frequentarem esse bar - suas homossexualidades poderiam ser publicadas por esses jovens "afeminados". Sobral é uma cidade pequena e "todos se conhecem e sabem da vida de todo mundo" (Dênis, 2014). O simples ato de frequentar o bar, embora não ficando ou paquerando com nenhum homem, já era considerado marca essencial para a população estigmatizar tal visitante de 'gay'. A maioria dos frequentadores permanecia nesse bar sob uma espécie de "proteção heterossexual”, ou seja, com amigos héteros ou com casais héteros.

${ }^{7}$ A expressão "fitness" designa tanto uma capacidade orgânica quanto um estilo ou jeito de ser e de se comportar (GOELLNER, SILVA, 2012). Na sociedade do culto ao corpo e do hiperconsumo, este termo vem sendo utilizado para justificar sentidos e valores sociais relacionados à prática de exercício físico. Os malhados representavam o estilo corporal hegemônico a ser perseguido para vencer a concorrência na paquera e na "catação".

${ }^{8}$ Termo êmico que se referia aos engajamentos amorosos e/ou sexuais não-homossexuais entre homens nas festas.

${ }^{9}$ Termo êmico que significa beijar ou "dar um amassos" (Neto, 2015) rápido com alguém sem demonstrar, inicialmente, intenção sexual.

${ }^{10}$ Publicar de alguma forma os "ficas" ou "pegações" homossexuais ocorridas nas festas.

${ }^{11}$ Metáfora analítica tomada de empréstimo de Norbert Elias e John Scotson (2000) para definir tanto os participantes mais assíduos das festas e que estavam familiarizados com os códigos de sociabilidade ("estabelecidos") quanto os frequentadores novatos ou que não estavam familiarizados com estes códigos (“outsiders").

${ }^{12}$ Termo êmico que representava os frequentadores afeminados que expressavam seu efeminamento através de performances de dança pop durante as festas.

${ }^{13}$ Locais semifechados, escuros, em que a ordem é a liberação da "pegação", ou melhor, práticas sexuais diversificadas. Quando as festas ocorriam nos motéis, um dos quartos das suítes era autorizado para ocorrer as "pegações".

${ }^{14}$ Expressão utilizada para se referir aos jovens que frequentavam quase todas as festas eletrônicas que ocorriam na cidade

${ }^{15}$ Festas eletrônicas organizadas com intuito de duração prolongada como, por exemplo, 12 ou 24 horas de duração.

${ }^{16}$ Supressão da palavra que identificava o colaborador. 
${ }^{17}$ Cantoras pop como Beyouncé, Lady Gaga, Rihana, Britney Spears e Katy Perry. Além da cantora de funk Anita. Elas são consideradas como um semideus por alguns frequentadores das festas eletrônicas, principalmente pelos os afeminados e que servem como inspiração coreográfica para suas performances de dança nos eventos (Ricardo, 2016).

${ }^{18}$ Tanto poderia ser o processo de paquera em si, quanto o sujeito paquerado, um "fica" atual ou alguém que se paquera sem o outro ter consciência de ser paquerado.

${ }^{19} \mathrm{O}$ "esquenta" significava beber sozinho e entre amigos em determinados bares, restaurantes ou casas de amigos. Nesse período de interação regada pelo álcool, os jovens conversavam sobre as festas que planejavam frequentar e se preparavam para possíveis flertes, comentando suas intenções em relação às festas e, às vezes, compartilhando pretensos parceiros já marcados via Facebook.

${ }^{20}$ Os olhares não se dirigiam apenas para um determinado participantes: não possuíam um único foco.

${ }^{21}$ Expressão êmica que objetivava nomear a situação interacional onde existia correspondência de desejos e interesses amorosos e/ou sexuais durante a paquera.

${ }^{22}$ A deferência - percebida em saudações, elogios e desculpas - é um meio simbólico de comunicar apreciação ou estima para um receptor ou para algo que ele simboliza ou representa (GOFFMAN, 2011: 59). É um componente básico da cerimônia e pode assumir a forma de "ritual de evitação" e "ritual de apresentação". Os rituais de evitação são empregados onde a deferência leva o ator a manter distância do receptor através de proscrições, proibições e tabus que objetivam respeitar esse direito do receptor (Ibid.:65). Os rituais de apresentação - segundo tipo de deferência
- funcionam para confirmar aos receptores que são estimados em determinada interação e sinalizam para o tratamento que está por vir, ou seja, eles especificam o que deve ser feito (Ibid.:72).

${ }^{23}$ Encontro social onde os indivíduos se juntam com a finalidade de sustentar um único foco de atenção visual e cognitiva (GOFFMAN, 2010: 101).

${ }^{24} \mathrm{~A}$ concepção de gênero enquanto performance, "repetição estilizada de atos", da filósofa Judith Butler (2010), foi crucial na problematização das concepções e práticas de masculinidades que eram encenadas e avaliadas pelos colaboradores.

${ }^{25}$ Essa denominação foi aplicada ao conjunto padronizado de comportamentos a serem encenados e compartilhados pelos integrantes de determinado grupo de amigos durante a festa. Essa "performance grupal" demarcava ações, atitudes, gostos, preferências e intencionalidades que qualquer integrante poderia possuir de acordo com os colaboradores. Neto assevera que determinado indivíduo que estava "na companhia" de outros que somente pensavam em "colecionar ficas" e beberem muito, geralmente não serviam "pra namorar". ${ }^{26}$ Alguns colaboradores ratificaram a presença de homens que não se identificavam como gays mas que gostavam de "ficar" com outros homens nas festas.

${ }^{27}$ Geralmente identificado como aquele sujeito de classe média ou alta que possuía escolaridade de nível superior e consumia as melhores e mais caras bebidas durante as festas (Ricardo, 2016).

${ }^{28}$ Termo criado por Wagner (1993) que identifica um conjunto de disposições discursos, valores e práticas - que naturaliza, sanciona e legitima a heterossexualidade como a única possibilidade de expressão dos sujeitos (JUNQUEIRA, 2012: 66). A heteronormatividade é sustentada pela 
heterossexualidade obrigatória - conforme Louro (2012). E, além disso, reforçada pela efeminofobia - medo ou pavor de se efeminar - no caso das relações amorosas e sexuais entre homens.

${ }^{29}$ Estilos de música caracterizados por batidas fortes - tribal - e fracas - house - e com pouca vocalidade (Ricardo, 2016).

\section{REFERÊNCIAS}

BUTLER, Judith. 2010. Problemas de Gênero: feminismo e subversão da identidade. 3.ed. Tradução de Renato Aguiar. Rio de Janeiro: Civilização Brasileira.

2002. Cuerpos que importan: sobre los limites materiales y discursivos del ‘sexo'. 1.ed. Buenos Aires: Paidós.

ELIAS, N. \& SCOTSON, J. L. 2000. Os estabelecidos e os outsiders: sociologia das relações de poder a partir de uma pequena comunidade. Rio de Janeiro: Jorge Zahar.

; DUNNING, E. 1992. A busca da excitação. Tradução de Maria Manuela Almeida e Silva. Lisboa: DIFEL.

GOELLNER, S. V. \& SILVA, A. L. S. 2012: 187-210. "Biotecnologia e neoeugenia: olhares a partir do esporte e da cultura "fitness"”. In: COUTO, Edvaldo Souza; GOELLNER, Silvana Vilodre (Orgs.). O triunfo do corpo: polêmicas contemporâneas. Petrópolis: Vozes.

GOFFMAN, E. 2011. Rituais de interação: ensaios sobre o comportamento face a face. Tradução de Fabio Rodrigues Ribeiro da Silva. Petrópolis: Vozes, [Coleção Sociologia].

2010.Comportamento em lugares públicos: notas sobre a organização social dos ajuntamentos. Tradução de Fabio Rodrigues Ribeiro da Silva. Petrópolis: Vozes, [Coleção Sociologia].
2009. A representação do eu na vida cotidiana. 16.ed. Tradução de Maria Celia Santos Raposo. Petrópolis: Vozes.

JUNQUEIRA, R. D. 2014. “A pedagogia do armário: heterossexismo e vigilância de gênero no cotidiano escolar". Revista Educação On-line, Rio de Janeiro, PUC, n. 10, p. 64-83, 2012. Disponível em: <http:// www.maxwell.lambda.ele.pucrio.br/rev_ edu_online.php?strSecao $=$ input $0>$. Acesso em: 20 mar.

PEIRANO, Mariza (Org.). 2001. O dito e o feito: ensaios de Antropologia dos rituais. Rio de Janeiro: Relumé Dumará.

SCHECHNER, R. 2012: 21-45. "Uma tarde com Richard Schechner - Os anos sessenta, a palavra performance e o nascimento dos Performance Studies" (Entrevista). In: LIGIÈRO, Zeca (Org.). Performance e Antropologia de Richard Schechner. Tradução de Augusto Rodrigues da Silva. Rio de Janeiro: Mauad X.

Recebido entre 24 a 27/02/17

Aprovado em 21/03/17 
